\title{
La configuración de los órganos de derecho público con carácter autónomo en México: el caso del Banco de México
}

\author{
Miguel Angel Medina Romero ${ }^{1}$ \\ miguel.medina.romero@umich.mx \\ Universidad Michoacana de San Nicolás de Hidalgo \\ Morelia, México
}

\section{RESUMEN}

Las instituciones cobran valor por el marco jurídico en que se fundamentan, por la política que las orienta y por los seres humanos que las integran. Por medio de reformas legales, resoluciones jurídicas o modificaciones constitucionales, los países han concedido, progresivamente, a sus bancos centrales la autonomía jurídica con respecto a otros sectores gubernamentales, con el fin de que la autoridad correspondiente promueva la orientación de la política monetaria para alcanzar la estabilidad de precios. El presente trabajo tiene por objetivo exponer algunas consideraciones en torno a la constitución de la banca central mexicana como institución de derecho público con carácter autónomo, a partir del planteamiento de un análisis bidisciplinario: jurídico y económico. El Banco de México, nuestro caso de estudio, desde su fundación fue dotado de una normatividad conducente y propiciatoria de un desempeño eficaz de su tarea: combatir la inflación, independientemente de coyunturas -como la actual crisis de salud pública por la enfermedad COVID-19 causada por el virus SARS-CoV-2- e ideologías, pues solo así la institución objeto de examen puede gestionar la estabilidad monetaria y promover el desarrollo económico en México.

Palabras clave: órganos de derecho público; autonomía; derecho; teoría económica; banco de méxico.

\footnotetext{
${ }^{1}$ Profesor e Investigador Titular en la Facultad de Derecho y Ciencias Sociales y en el Centro de Investigaciones Jurídicas y Sociales de la Universidad Michoacana de San Nicolás de Hidalgo.
} 


\title{
Formation of public law institutions with autonomy in Mexico: the case of Banco de Mexico
}

\begin{abstract}
The value of the institutions depends as much on their legal framework as its policy guidance and respectful of their constituent persons. Countries have given legal autonomy, progressively, to their central banks by means of legal reforms, legal resolutions or constitutionals amendments. The objective of this study is to present some considerations on the formation of the Mexican central bank as an autonomous public law institution, base don a bi-disciplinary analysis: legal and economic. Banco de Mexico, our case study, was endowed from its foundation with regulations conducive and conducive to the effective performance of its task: to fight inflation, regardless of circumstances -such as the current public health crisis caused by the COVID-19 disease caused by the SARS-CoV-2 virus- and ideologies, because only in this way can the institution under examination manage monetary stability and promote economic development in Mexico.
\end{abstract}

Key words: institutions of public law; autonomy; law; economic theory; banco de Mexico.

Artículo recibido: 05 octubre. 2021 Aceptado para publicación: 02 noviembre 2021 Correspondencia: miguel.medina.romero@umich.mx Conflictos de Interés: Ninguna que declarar 


\section{INTRODUCCIÓN}

En un considerable número de naciones, recientemente el concepto de la autonomía de la banca central se ha venido constituyendo en una especie de regla para la organización y el funcionamiento de esta última. Consecuentemente, mediante reformas legales, resoluciones jurídicas o modificaciones constitucionales, distintos países, progresivamente, les han concedido a sus bancos centrales la autonomía jurídica con respecto a otros sectores gubernamentales, con el fin de que la autoridad correspondiente promueva la orientación de la política monetaria hacia el objetivo de la consecución de la estabilidad de precios (Friedman, M., 1963; Martínez, R., 1942; Mishkin, F., 2008).

Además, también la teoría económica ha progresado en la dirección de proponer la autonomía de la autoridad monetaria como mecanismo formal para incrementar la credibilidad del compromiso antiinflacionario de la misma (Martínez, R., 1944). La evidencia empírica, por su parte, advierte que mientras mayor sea la credibilidad del público en el compromiso de abatimiento de la inflación de la autoridad, más fácilmente podrá alcanzarse el objetivo de estabilidad de precios (Tamagna, F., 1963; Thompson, J., 1979; Fernández, E., 1976; Fernández Leal., 1963).

Este trabajo tiene como objetivo presentar algunas consideraciones en torno al Banco de México como institución de derecho público con carácter autónomo, a partir del planteamiento de una visión bidisciplinaria: jurídica y económica. Para tal propósito, la siguiente sección da cuenta de un breve análisis teórico y conceptual sobre el principio de la división del poder, la autonomía y los órganos autónomos en México. La tercera parte describe el vínculo que se presenta entre el banco central y la teoría económica.

En una cuarta sección se articula el conjunto de hechos históricos más relevantes que han marcado el desarrollo del Banco de México, y a través quinta parte se presenta el sustento teórico del Banco de México como persona de derecho público con carácter autónomo. La sexta sección aborda la autonomía del Banco de México, en la estimación de que la misma significó el arribo definitorio de la institución hacia la modernidad legal y económica. Y las últimas partes del estudio presentan algunas consideraciones finales, así como los datos de las fuentes de referencia empleadas en esta producción.

\section{La división del poder, la autonomía y los órganos autónomos en México}

Desde una perspectiva política, el principio de la división del poder consiste en suponer 
que este último "está distribuido entre distintos órganos que mutuamente se frenan, (por lo que) queda cerrada la posibilidad de que el poder constituido se haga ilimitado, soberano" (Rubio, 1997, p. 210). Así mismo, dicho principio se fundamenta en la idea de que el abuso y la arbitrariedad cobran vigencia cuando, precisamente, no se cuenta con un poder con límites (Agapito, 1989).

En el caso de México, la de división del poder viene a constituir el eje estructural del Estado mexicano, promoviéndose así una coordinación entre los poderes Ejecutivo, Legislativo y Judicial, tal y como lo prevé la Constitución. No obstante, la moderna teoría de la división del ejercicio del poder, desde hace décadas, ha construido los denominados órganos constitucionales autónomos que ciertamente no pertenecen a la división clásica del poder, pero que llevan a cabo funciones de primer orden y forman parte de los órganos del Estado (Pedroza, S., 2002). ${ }^{2}$

Un atributo fundamental de estos órganos los es la autonomía, es decir, una forma de división del poder, sin que ésta deba ser concebida como soberanía, o sea, que ha de entenderse como la distribución de competencias sobre determinadas materias (Borja López-Jurado, F., 1991). La autonomía de un órgano supone que es sujeto de derecho y obligaciones, capaz de adquirir, de demandar y, en general, de efectuar actos jurídicos frente a terceros, o sea, existe un ente distinto a sus miembros, goza de personalidad jurídica (Matheus, M., 1995).

En este contexto, el Estado mexicano ha adoptado la teoría de los órganos constitucionales autónomos, y bajo ese esquema, a partir de la década de los ochenta, la Constitución señala a cinco entidades como autónomas: Las universidades a las que la ley otorgue tal carácter, en el artículo $3^{\circ}$, fracción VII (Constitución Política de los Estados Unidos Mexicanos, 1980); el Banco de México, en el artículo 28, párrafo 6 (Constitución Política de los Estados Unidos Mexicanos, 1993); el Instituto Federal Electoral, en el artículo 41, fracción III; (Constitución Política de los Estados Unidos Mexicanos, 1996) la Comisión Nacional de Derechos Humanos, en el artículo 102 "B" (Constitución Política de los Estados Unidos Mexicanos, 1999); y los Tribunales

\footnotetext{
${ }^{2}$ La teoría sostiene que los rasgos de esos órganos constitucionales autónomos son, entre otros, la inmediatez, la esencialidad, dirección política, paridad de rango y la autonomía. La inmediatez implica que son órganos creados directamente desde la Constitución; la esencialidad tiene que ver con que las funciones que les son encomendadas resultan necesarias para la construcción y preservación de los estados democráticos; la paridad de rango implica que no les resta jerarquía frente a los otros poderes estatales, por lo que deben actuar coordinadamente con los otros órganos; y la autonomía orgánica y funcional, que no implica independencia.
} 
Agrarios, en el artículo 27, fracción XIX (Constitución Política de los Estados Unidos Mexicanos, 1992).

Los siguientes espacios habrán de centrarse en la descripción y el análisis del Banco de México, en tanto entidad del Estado, de interés público y portadora de autonomía como rasgo de su naturaleza jurídica.

\section{El banco central y la teoría económica}

La relación que existe entre al Banco de México y la teoría económica puede apreciarse si se advierte que esta última describe los principales avances teóricos que han dado sustento a la autonomía de las autoridades monetarias (Schwartz, M., y Galbán, S., 1999, pp. 4-7). Así, tanto académicos como autoridades han supuesto que aislar a la política monetaria de las decisiones políticas facilita la consecución de la estabilidad de precios, y permite que ésta se alcance a un menor costo en términos de actividad económica y empleo.

Esta tesis se basa en la aceptación de que la mejor manera en que la política monetaria puede servir al interés público, es propiciando un ambiente monetario y financiero estable para el desarrollo de la actividad económica, a través de la instrumentación de una política monetaria orientada al abatimiento de la inflación. Y, con base en lo anterior, un número importante de países le ha otorgado independencia a sus bancos centrales, asignándoles el mandato de encaminar su política hacia la consecución de la estabilidad de precios.

No supone novedad advertir que el proceso inflacionario genera un sinnúmero de costos para el adecuado funcionamiento de una economía. La incertidumbre y la volatilidad que caracterizan a la inflación se reflejan en la ineficiente asignación de recursos productivos, tanto entre sus distintos usos como en el tiempo, y en una inequitativa distribución del ingreso.

Así, la conveniencia de contar con bancos centrales autónomos que tengan como su objetivo prioritario la procuración de la estabilidad de precios, se sustenta en dos hechos estilizados: a) La curva de Phillips de largo plazo es vertical, situación que supone que en tal espacio temporal el incremento de precios no posee un efecto permanente en el nivel de empleo, y b) los gobiernos son proclives a generar inflación en pos de reducir los márgenes de desempleo. 
La independencia de la banca central es un elemento que propicia un prudente manejo monetario, y por consiguiente favorece el abatimiento de la inflación. Sin embargo, el éxito sostenible en la lucha contra la inflación requiere, además de un adecuado manejo monetario, de la concurrencia de los distintos sectores de la sociedad.

Se requiere, pues, entre otros factores, de la instrumentación de políticas fiscales sólidas, del convencimiento de las autoridades que abatir la inflación es deseable y que sus acciones reflejen la importancia de alcanzar dicho objetivo, de la cooperación de otras medidas de política, y del convencimiento de la población en general de que abatir la inflación redundará en beneficios para toda la sociedad. Por otra parte, las distorsiones y rigideces de algunos mercados pueden obstruir el proceso antiinflacionario, por lo que las reformas estructurales que propician la eficiencia en los distintos mercados, facilitan el logro de la estabilización de precios.

El banco central enfrenta el reto de abatir la inflación, adquirir credibilidad y reputación de autoridad comprometida con la lucha antiinflacionaria, en un entorno en el que, en el corto plazo, factores distintos a los monetarios, y por lo tanto ajenos a su control, pueden incidir en forma importante sobre la evolución de los precios. Más aún, la política monetaria enfrenta la dificultad adicional de que sus acciones actúan con cierto rezago sobre el comportamiento de los precios.

Ante el escenario descrito, tanto la teoría económica como la evidencia empírica, sugieren los siguientes elementos para mejorar la credibilidad de la banca central, y por consiguiente, facilitar el proceso de abatimiento de la inflación: 1) El banco central debe tener un mandato claro y definido orientado a procurar la estabilidad de precios; 2) la autoridad monetaria debe anunciar públicamente sus objetivos, y los mecanismos con los que pretende alcanzar dichas metas; 3) la instrumentación de la política monetaria debe realizarse, en lo posible, a través de mecanismos de mercado; 4) el banco central debe responsabilizarse de sus actos y justificar su proceder ante las instancias legislativas y el público en general; 5) con el objeto de poder alcanzar sus metas, la autoridad monetaria debe gozar de "independencia de instrumentos"; 6) las acciones de política oportunas del banco central resultan fundamentales para afectar las expectativas inflacionarias del público, y por lo tanto facilitan el abatimiento de la inflación; 7) la credibilidad en la política monetaria se logra a través de la instrumentación sostenida de políticas encaminadas a la reducción de la inflación; y 8) entre mayor sea el consenso de 
la sociedad y del resto de las políticas económicas de la relevancia de alcanzar la estabilidad de precios, más rápida y menos costosa será su consecución.

\section{Concepción y trayectoria del Banco de México}

Los primeros antecedentes del Banco de México se remontan al menos hasta principios del siglo XIX, aunque los antecedentes inmediatos de esta institución fueron registrados a partir de la destrucción del sistema bancario porfirista durante la Revolución y la aparición del proyecto del Banco Único de Emisión que fue consagrado en el Artículo 28 de la Carta Magna promulgada en 1917 (Manero, A., 1926; Heath, J., 2007; Aguilera, M., 2014). Empero, la fundación del Banco de México tuvo verificativo hasta el $1^{\circ}$ de septiembre de 1925 , en un solemne acto presidido por el primer mandatario, Plutarco Elías Calles (Turrent, E. 2015a).

Las necesidades de propiciar el surgimiento de un nuevo sistema bancario, hacer renacer el crédito en el país y reconciliar a la población con el uso del papel moneda justificaron el nacimiento del Banco de México (Manero, A., 1926). Así, a la institución recién activada se le entregó, en exclusiva, la facultad de crear moneda, tanto mediante la acuñación de piezas metálicas como a través de la emisión de billetes (Martínez, R., 1970). Y, como consecuencia correlativa de lo anterior, se le encargó la regulación de la circulación monetaria, de los tipos de interés y del cambio sobre el exterior. El nuevo órgano, asimismo, se convirtió en agente, asesor financiero y banquero del Gobierno Federal, aunque se dejó en libertad a los bancos comerciales para asociarse o no con el Banco de México; y, además de los atributos propios de un banco de emisión, se le otorgaron también facultades para operar como institución ordinaria de crédito y descuento (Moore, E., 1963).

Registrada su fundación, el Banco debió trabajar en pos de su propósito de consolidarse como banco central. En el contexto de la recesión mundial del 29, en julio de 1931 se promulgó una Ley Monetaria por la cual se desmonetizaba el oro en el país (Ortiz, R., 1942). ${ }^{3}$ Paralelamente, se promulgó una nueva Ley Orgánica para el Banco de México que retiró al Banco las facultades para operar como banco comercial, e hizo obligatoria la asociación de los bancos con el Instituto Central y flexibilizó las reglas para la emisión de billetes (Rosenzweig, F., 1965). Otras funciones señaladas en la Ley Orgánica de México fueron las de regular la circulación monetaria, la tasa de interés y

\footnotetext{
${ }^{3}$ En cuanto al Banco de México, dicha Ley confirió ciertas características de moneda a sus billetes, aun cuando se conservó la libre aceptación de los mismos.
} 
los cambios sobre el exterior; encargarse del servicio de la Tesorería del Gobierno Federal; centralizar las reservas bancarias y convertirse en banco de los bancos y en prestamista de última instancia (Secretaría de Hacienda y Crédito Público, 1933).

Hacia 1935 se alcanzó una elevación ininterrumpida del precio de la plata, lo que significaba un grave riesgo de que el valor intrínseco de las monedas de ese metal superara a su valor facial (Septién, A., 1935). Para superar la crisis platista, se emitieron piezas con menor contenido de plata, y se pusieron en circulación billetes de esa denominación (Sherwell, B., 1929).

Una nueva y ortodoxa Ley Orgánica fue promulgada en 1936, la cual respondió al interés de librar a la operación del Banco de México de toda nota inflacionista, a partir de la adopción de reglas para la emisión de medios de pago, empero, dado su nivel de restricción, en 1938 se reformaron sus disposiciones referentes a los límites del crédito que el Banco pudiese otorgar al Gobierno, como respecto al tipo de papel que el mismo pudiese adquirir en sus operaciones con los bancos comerciales (Bett, V., 1957).

Siguiendo el curso de la historia, el periodo de la Segunda Guerra Mundial que se extendió aproximadamente de 1940 a 1945 fue de gran trascendencia en la evolución del Banco de México (Secretaría de Hacienda y Crédito Público, 1958). Ya en los comienzos de ese tiempo bélico, a finales de 1939, la economía de México se vio inundada con los capitales flotantes o golondrinos que buscaron refugio bancario en el país e hincharon la reserva monetaria del Banco, dando lugar a una acelerada expansión de los medios de pago, expansión preñada de un ominoso potencial inflacionario (Fernández Leal, R., 1963). Por lo tanto, en aras de conjurar esa posibilidad, las autoridades fueron definiendo y aplicando una política de contención monetaria. Fue así que se desarrollaron los mecanismos de regulación apropiados para un Banco Central que operaba en un medio donde no existían mercados financieros dignos del nombre, por lo que en 1941 se promulgó un nuevo encuadre legal para las materias bancaria y financiera, y de ahí surgieron una nueva Ley Bancaria, así como una nueva Ley Orgánica del Banco de México (Borja, F., 1979).

Finalizada la Segunda Guerra Mundial, México había sido uno de los países suscriptores del convenio de Bretton Woods, mediante el cual se acordó, entre otras cosas, un sistema de tipos de cambio fijos para las monedas del mundo. A pesar de ello, México optó por dejar en flotación la tasa de cambio del peso y luego ensayó nuevos 
ajustes cambiarios (De Beers, J., 1953). Además, hacia 1948 y 1949, el país sufrió dos severas crisis de balanza de pagos atribuibles, en gran medida, a los reacomodos y ajustes de la economía mundial típicos de la postguerra. En ese período, al tenerse registro nuevamente de una preocupante entrada de divisas, se reformó la Ley Bancaria y se otorgó al Instituto Central la facultad potestativa de elevar el encaje de la banca comercial hasta el 100\% sobre el crecimiento de sus pasivos (Ugarte, S., 1950). ${ }^{4}$

Durante el lapso 1954-1970, México experimentó un esquema de progreso y estabilidad que se conoció como el desarrollo estabilizador. Este momento fue precedido por una etapa de crecimiento con inestabilidad que se extendió por más de tres lustros y que culminó con los ajustes cambiarios antes referidos. Así, en el desarrollo estabilizador el producto real creció a un ritmo muy superior al de la población, lo cual posibilitó que también crecieran ininterrumpidamente tanto el ingreso per cápita como los salarios reales y, en particular, el sector financiero experimentó un notorio progreso, siendo todo ello, en gran medida, resultado de la aplicación de una atinada política monetaria por parte del Banco de México (Ortiz, A., 1998).

Llegados los años setenta y parte de los ochenta, se extendió una etapa de luces y sombras para el Banco. Así, en 1976 sobresalió una importante iniciativa efectuada por el Banco de México en torno a la creación en México de la denominada banca múltiple. Y, una vez consumada la conversión de la banca de especializada en múltiple, se promovió un programa de fusiones de instituciones pequeñas orientado a fortalecer su solidez y a procurar una mayor competitividad en el sistema financiero (Fernández, E., 1976). Además, entre otras aportaciones memorables del Banco Central, cabe recordar la idea de reglamentar la capitalización de los bancos no sólo en función de su captación, sino de ciertos activos y de otros conceptos expuestos a riesgo (Fernández Leal, R., 1963). E igualmente merecen mención la concepción y el establecimiento de un sistema de protección para los depósitos del público en la banca, así como la creación, en 1978, de los Certificados de la Tesorería (Cetes). ${ }^{5}$

\footnotetext{
${ }^{4}$ Sin embargo, esta obligación se graduó en función de la forma en que las instituciones integrasen sus carteras de crédito o, en otras palabras, de acuerdo a la manera en que canalizaran su financiamiento a los distintos sectores de la economía.

${ }^{5}$ Estos títulos, previa la promulgación en 1975 de una nueva Ley Reglamentaria del Mercado de Valores, fueron la base para el desarrollo en México de un mercado de bonos y valores de renta fija. De importancia es destacar la trascendencia de dicho logro no sólo en cuanto a la evolución financiera de México, sino también respecto al progreso de la banca central en este país. La creación y la madurez del
} 
Por otro lado, las dificultades que debió enfrentar el Banco de México en el período aludido tuvieron su génesis en la instauración de políticas económicas excesivamente expansivas y en la obligación que se impuso al Banco de extender amplio crédito para financiar los deficientes fiscales en que entonces se incurrió (Gómez, A., 1981). De esa forma se dio lugar al deterioro de la estabilidad de los precios y fue causa de que se verificaran dos severas crisis de balanza de pagos en 1976 y 1982.

Posterior a las crisis de referencia, el sentido de las acciones encabezadas por el Banco debió cambiar, en lo fundamental, hacia el control de la inflación, la corrección de los desequilibrios de la economía y la procuración de la recuperación de la confianza de los agentes económicos (Solís, L., 2000, pp. 388-398). En este contexto, ya en la administración del presidente Miguel de la Madrid (1982-1988), fue creado el Fideicomiso para la Cobertura de Riesgos Cambiarios (FICORCA), instrumento que no sólo permitió que, en su momento, las empresas mexicanas con pasivos denominados en divisas pudieran renegociar sus adeudos externos sino, a la vez, que quedasen protegidas contra el riesgo eventual de futuros ajustes del tipo de cambio (Turrent, E., 2015c).

Igualmente, en 1985 se expidió una nueva Ley Orgánica para la institución, ordenamiento que se distinguió porque incorporó en su texto la facultad de fijar límites adecuados al financiamiento que pudiese otorgar la institución. Otras características notables de esa Ley fueron que otorgó al Banco la posibilidad de emitir títulos de deuda propios para fines de regulación monetaria, y liberó a la reserva monetaria de restricciones a fin de que la misma pudiese ser usada sin cortapisas para los fines que le son propios (Borja, F., 1995, pp. 12-19).

\section{EI Banco de México, institución de derecho público con carácter autónomo}

La regulación del Banco de México forma parte de los contenidos del artículo 28 constitucional, concebido originalmente como la garantía de libre concurrencia; además, y especialmente a partir de las reformas de 1983, parte integrante del capítulo económico de la Constitución, que prevé la responsabilidad del Estado como ente rector en los procesos de planeación y conducción de la vida económica nacional.

La autonomía prevista en la Constitución se otorga en términos de ejercicio de funciones y administración, con lo cual se incrementa su competencia técnica en una cabo, en la práctica, la regulación monetaria a través de operaciones de mercado abierto. 
actividad de primer orden para la viabilidad económica de la Nación, como es la estabilidad de precios, y que debe mantenerse ajena a consignas políticas y a una injerencia excesiva del Poder Ejecutivo (Turrent, E., 2012). La descripción de la naturaleza jurídica de la entidad no precisa en ningún momento su carácter como órgano constitucional autónomo, como ocurre en todos los casos de autonomía previstos en el Máximo Ordenamiento (Turrent, E., 2005).

En su origen, el Banco de México persiguió como propósito principal la armonización del control monetario ordenado por la Constitución con una conveniente autonomía (Ley Constitutiva del Banco de México, 1925). Empero, con la contrarreforma de 1936, la institución de referencia debió financiar todos los pedidos del gobierno federal de aquella época, situación que culminó en un caos financiero y monetario (Ley Orgánica del Banco de México, 1936).

Con el registro de la reforma de 1993, el Banco de México pudo retomar el carácter de organismo descentralizado, pues la Ley del Banco de México, reglamentaria de los párrafos sexto y séptimo del artículo 28, y publicada el 23 de diciembre de 1993, señala en su artículo primero que el banco central será una persona de derecho público con carácter autónomo, aunque, a partir de una relación de revisión de legalidad, tiene que rendir cuentas al Congreso de la Unión, en los términos en que lo hacen otras instituciones que no escapan a la supervisión ni al escrutinio de la cuenta pública y tampoco a la disposición constitucional de autorización presupuestal o al control de la Ley de Ingresos, donde se señalan los ingresos permisibles para el gobierno Federal incluidos los instrumentos de política monetaria (Ley Orgánica del Banco de México, 1993).

Así, hoy por hoy, el Banco de México es una institución que, por mandato constitucional, tiene el papel de banco central autónomo en México, dada la participación preferente que tiene como entidad rectora de la operación de las instituciones bancarias del Estado mexicano (Carbonell, M., 2005, 42-45). Es un organismo público descentralizado del Gobierno Federal, que se regula por su Ley Orgánica, la cual contempló que:

El Banco de México tendrá por finalidad proveer a la economía del país de moneda nacional. [...] Tendrá como objetivo prioritario procurar la estabilidad del poder adquisitivo de dicha 
moneda. [Y,] también [...] promover el sano desarrollo del sistema financiero y propiciar el buen funcionamiento de los sistemas de pagos (Ley Orgánica del Banco de México, 1993). ${ }^{6}$

Por mandato de ley, la conducción del Banco de México está a cargo de la Junta de Gobierno, órgano colegiado que se encuentra conformado con un gobernador y cuatro subgobernadores, funcionarios que son designados por el Ejecutivo, pero no pueden destituidos de su cargo discrecionalmente; los periodos de servicio de esos funcionarios son alternados; el del gobernador dura seis años y empieza en la mitad de un sexenio gubernamental para concluir al cierre de los tres primeros años del siguiente; y los periodos de servicio de los subgobernadores duran ocho años y su reemplazo está alternado cada dos (Ley Orgánica del Banco de México, 1993).

\section{La modernidad legal y económica del Banco de México}

Sin duda, el ingreso definitorio a la modernidad por parte del Banco de México se inició con el otorgamiento de su autonomía, la cual implica, en términos prácticos, que ninguna autoridad pueda exigirle la concesión de crédito, con lo cual se garantiza el control ininterrumpido del instituto central sobre el monto del dinero (billetes y monedas) en circulación (Turrent, E., 2012, pp. 59-96). Además, la finalidad de la autonomía es que la operación del banco central sea conducente a la conservación del poder adquisitivo de la moneda nacional, o sea, que los precios de todas las cosas se mantengan estables a lo largo del tiempo.

Así las cosas, la autonomía del Banco de México está sustentada en tres bases fundamentales. La primera de ellas es de naturaleza legal y se integra en su parte medular con el mandato constitucional que establece que la misión prioritaria de la institución es la procuración del mantenimiento del poder adquisitivo de la moneda nacional. Este objetivo está también especificado en la ley actualmente en vigor del

\footnotetext{
${ }^{6}$ Además:

"El Banco desempeñará las funciones siguientes: I. Regular la emisión y circulación de la moneda, los cambios, la intermediación y los servicios financieros, así como los sistemas de pagos; II. Operar con las instituciones de crédito como banco de reserva y acreditante de última instancia; III. Prestar servicios de tesorería al Gobierno Federal y actuar como agente financiero del mismo; IV. Fungir como asesor del Gobierno Federal en materia económica y, particularmente, financiera; V. Participar en el Fondo Monetario Internacional y en otros organismos de cooperación financiera internacional o que agrupen a bancos centrales, y VI. Operar con los organismos a que se refiere la fracción $\mathrm{V}$ anterior, con bancos centrales y con otras personas morales extranjeras que ejerzan funciones de autoridad en materia financiera" (Ley Orgánica del Banco de México, 1993).
} 
Banco de México promulgada a finales de 1993 (Ley Orgánica del Banco de México, 1993).

La segunda base reside en el formato de integración de la Junta de Gobierno y las normas a que está sujeto su funcionamiento. Ese órgano colegiado se encuentra conformado con un gobernador y cuatro subgobernadores, funcionarios que son designados por el Ejecutivo pero no pueden destituidos de su cargo discrecionalmente. ${ }^{7}$ Y la tercera base de la autonomía del Banco de México radica en la independencia administrativa que el marco jurídico vigente le concede a esta institución.

Además, la recepción del carácter autónomo por parte del Banco Central también ha de vincularse necesariamente con la modernidad económica. Y esta última, irrenunciablemente, pugna por combatir el fenómeno de la inflación y los múltiples males que causa, especialmente por lo que toca a la distribución del ingreso y a las posibilidades de crecimiento económico.

La evidencia empírica apunta que, en épocas de inflación, los precios crecen más aceleradamente que los salarios, a la vez que dicho fenómeno afecta en mayor medida a quienes tienden a conservar sus recursos en billetes y monedas (Grove, D., 1955; Mendoza-Velazquez, A., 2009; Palafox, C., 2011; Salas, O., 2018). Y en general, los individuos en esta última situación son los que pertenecen a los estratos más desfavorecidos de la sociedad.

En cuanto al crecimiento, la inflación tiende a deteriorar los incentivos hacia la producción y la inversión, por la incertidumbre y el desconcierto que crea. Cuando existe inflación, la volatilidad de los precios relativos reduce la eficacia del mercado como mecanismo para la asignación de los recursos y falsea el cálculo económico, inhibiendo la inversión. Asimismo, el crecimiento acelerado y desordenado de los precios propicia tasas de interés elevadas, por el premio que los ahorradores demandan para las inversiones financieras.

Por lo tanto, la autonomía del Banco de México constituye un instrumento ideal promotor del combate contra la inflación en la medida en que no está dirigida a paliar sus síntomas, sino a evitar sus causas (Turrent, E., 2012, pp. 167-206). Ello, porque está

\footnotetext{
${ }^{7}$ Los periodos de servicio de esos funcionarios son alternados. El del gobernador dura seis años y empieza en la mitad de un sexenio gubernamental para concluir al cierre de los tres primeros años del siguiente. Y los periodos de servicio de los subgobernadores duran ocho años y su reemplazo está alternado cada dos.
} 
encaminada a impedir un uso abusivo del crédito del instituto emisor, fuente principal del mal a que se ha aludido.

\section{CONSIDERACIONES FINALES}

El Banco de México está cumpliendo noventa y seis años de existencia. A menos de un año del otorgamiento de su autonomía, esta institución debió afrontar junto con la Secretaría de Hacienda y Crédito Público las crisis de balanza de pagos y bancaria que se manifestaron durante los primeros meses de 1995. La crisis bancaria se resolvió principalmente mediante mecanismos fiscales $\mathrm{y}$, por su parte, la crisis de balanza de pagos y sus sucesivas devaluaciones dieron lugar a esfuerzos de estabilización en gran escala para erradicar la inflación.

Las instituciones valen por el marco jurídico en que se fundamentan, por la política que las orienta y por los seres humanos que las integran. Desde su fundación, el Banco de México ha sido dotado de marcos jurídicos conducentes y propiciatorios de un desempeño eficaz en el desarrollo de sus labores. Y en este orden es imperativo destacar de forma puntual la reforma que entró en vigor en abril de 1994, por la cual se dotó de autonomía al banco central de este país, ya que con ello se otorgó al Banco de México el estatus idóneo para cumplir su cometido fundamental: la procuración de la estabilidad de la moneda nacional.

Así, el tránsito hacia la autonomía por parte del Banco de México representó, igualmente, su paso definitorio a la modernidad. Y en la hora actual, no cabe duda que los países más exitosos en la lucha contra la inflación han sido aquéllos que han optado por la autonomía de su banca. Sin embargo, dicho arreglo institucional ha de advertirse tan sólo como un requisito en el avance hacia la dirección adecuada para propiciar la reducción sostenible del ritmo de crecimiento de los precios. Destacamos y concluimos, en definitiva, que es imperativo consolidar el carácter autónomo del Banco de México y reforzar el combate contra la inflación, independientemente de coyunturas -como la actual crisis de salud pública por la enfermedad COVID-19 causada por el virus SARSCoV-2- e ideologías, pues solo así nuestro banco central puede constituirse como una efectiva institución gestora de la estabilidad monetaria y promotora del desarrollo económico en México. 


\section{LISTA DE REFERENCIAS}

Agapito, R. (1989). Libertad y división de poderes. España: Tecnos.

Aguilera, M. (2014). La banca en México. Origen, evolución y perspectivas -economía política de las finanzas-. México: Universidad Nacional Autónoma de México.

Alesina, A., y Summers, L. (1993). Central Bank Independence and Macroeconomic Performance. Journal of Money Credit and Banking, 25(2), 151-162.

https://doi.org/10.2307/2077833

Banco de México. (S/a). Semblanza histórica del Banco de México. México: Banco de México. Recuperado de www.banxico.org.mx

Bett, V. (1957). Central Banking in Mexico: Monetary Policies and Financial Crisis, 1864-1940. U.S.A.: University of Michigan.

Borja, F. (1979). Orígenes del banco central en México. México: Banco de México.

Borja, F. (1995). El nuevo régimen del Banco de México. En Comercio exterior, 45(1), 12-19. Recuperado de

http://revistas.bancomext.gob.mx/rce/magazines/305/2/RCE2.pdf

Borja López-Jurado, Francisco de. (1991). La autonomía de las universidades como derecho fundamental: la construcción del Tribunal Constitucional. España: Civitas.

Carbonell, M. (2005). Constitución Política de los Estados Unidos Mexicanos. México: Instituto de Investigaciones Jurídicas de la Universidad Nacional Autónoma de México.

Constitución Política de los Estados Unidos Mexicanos. (1980). Reforma publicada en el Diario Oficial de la Federación del 9 de junio. México: Diario Oficial de la Federación.

Constitución Política de los Estados Unidos Mexicanos. (1992). Reforma publicada en el Diario Oficial de la Federación (DOF) del 6 de enero. México: Diario Oficial de la Federación.

Constitución Política de los Estados Unidos Mexicanos. (1993). Reforma publicada en el Diario Oficial de la Federación del 20 de agosto. México: Diario Oficial de la Federación. 
Constitución Política de los Estados Unidos Mexicanos. (1996). Reforma publicada en el Diario Oficial de la Federación del 22 de agosto. México: Diario Oficial de la Federación.

Constitución Política de los Estados Unidos Mexicanos. (1999). Reforma publicada en el Diario Oficial de la Federación (DOF) del 13 de septiembre. México: Diario Oficial de la Federación.

De Beers, J. (1953). El peso mexicano, 1940-1949. En Problemas Agrícolas e Industriales de México, enero-marzo.

Fernández Leal, R. (1963). Los acontecimientos económicos de México y la política monetaria, 1929-1946. México: (s/e).

Fernández, E. (1976). Cincuenta años de la banca central: ensayos conmemorativos, 1925-1975. México: Fondo de Cultura Económica.

Friedman, M., y Schwartz, A. (1963). A Monetary History of the United States, 18671960. U.S.A.: Princenton University Press.

Fix-Zamudio, H. (1987). Algunas reflexiones sobre el principio de la división de poderes en la Constitución mexicana. En Memoria del III Congreso Iberoamericano de Derecho Constitucional (pp. 597 y ss). México: Universidad Nacional Autónoma de México. México.

Fix-Zamudio, H., y Fix-Fierro, H. (2000). Constitución Política de los Estados Unidos. Comentada y concordada. México: Universidad Nacional Autónoma de México y Porrúa.

García, J. (1977). La autonomía universitaria en América Latina, mito y realidad. México: Universidad Nacional Autónoma de México.

Gil, R. (2000). ¿Qué son los órganos constitucionales autónomos? En Revista de la Barra Mexicana, 26(1), 36-41.

Gómez, A. (1981). Políticas monetaria y fiscal de México. La experiencia desde la posguerra. México: Fondo de Cultura Económica.

Grossi, P. (1997). Un derecho sin Estado. La noción de autonomía como fundamento de la Constitución jurídica medieval. En Anuario Mexicano de Historia del Derecho. México: Universidad Nacional Autónoma de México.

Grove, D. (1955). Política monetaria en países subdesarrollado. México: Centro de Estudios Monetarios Latinoamericanos. 
Heath, J. (2007). Para entender el Banco de México. México: Nostra Ediciones.

Ley Constitutiva del Banco de México (25 de agosto de 1925). (1958). En Legislación sobre el Banco de México. México: Secretaría de Hacienda y Crédito Público.

Ley Orgánica del Banco de México (28 de agosto de 1936). (1936). En Legislación sobre el Banco de México. México: Secretaría de Hacienda y Crédito Público.

Ley Orgánica del Banco de México. (1993). Diario Oficial de la Federación del 23 de diciembre. México: Diario Oficial de la Federación.

Manero, A. (1926). El Banco de México: Orígenes y fundación. U.S.A.: (s/e).

Manero, A. (1957). La revolución bancaria en México, 1865-1955. Una contribución a la historia de las instituciones de crédito en México. México: Talleres Gráficos de la Nación.

Martínez, R. (1942). El Banco de México frente a la teoría de la banca central. En Investigación Económica, (3).

Martínez, R. (1944). Algunos aspectos de la política monetaria del Banco de México. En El Trimestre Económico, julio-septiembre.

Martínez, R. (1970). El Banco de México. En De Hock, M. Banca central. México: Fondo de Cultura Económica.

Matheus, M. (1995). Relaciones de los institutos autónomos con la administración central. En Cuestiones Políticas, 14(1).

Mendoza-Velazquez, A. (2009). Monetary Policy Analysis in Emerging Markets. The Modelling of Conditional Volatility in Mexico and other Developing Countries. Germany: VDM Verlang.

Mishkin, F. (2008). Moneda, banca y mercados financieros. México: Pearson Educación.

Moore, E. (1963). Evolución de las instituciones financieras en México. México: Centro de Estudios Monetarios Latinoamericanos.

Ortiz, A. (1998). El desarrollo estabilizador: reflexiones sobre una época. México: El Colegio de México y Fondo de Cultura Económica.

Ortiz, R. (1942). La moneda mexicana. México: Editorial América.

Palafox, C. (2011). Política monetaria en México. México: Pearson. 
Pedroza, S. (2002). Los órganos constitucionales autónomos en México. En Serna, J., y Caballero, J. (Editores), Estado de derecho y transición jurídica (pp. 173-194).

México: Universidad Nacional Autónoma de México. Recuperado de https://archivos.juridicas.unam.mx/www/bjv/libros/1/306/7.pdf

Rosenzweig, F. (1965). Moneda y bancos. En Cosío, D., et al., Historia moderna de México: el porfiriato. La vida económica, vol. II, t. II. México: Editorial Hermes.

Rubio, F. (1997). La forma de poder. Estudios sobre la Constitución. España: Centro de Estudios Constitucionales.

Salas, O. (2018). Política monetaria de Banxico y sus herramientas macroprudenciales. Modelo de regresión VaR. España: EAE.

Schwartz, M., y Galbán, S. (1999). Teoría económica y credibilidad en la política monetaria. En Documento de Investigación, (9901). México: Banco de México.

Secretaría de Hacienda y Crédito Público. (1933). La crisis económica en México y la nueva legislación sobre la moneda y el crédito. Vol. I. México: Editorial Cultura.

Secretaría de Hacienda y Crédito Público. (1958). Legislación sobre el Banco de México. México: Secretaría de Hacienda y Crédito Público.

Septién, A. (1935). El Banco de México y la deflación monetaria. México: Publicaciones de la Academia Mexicana de Jurisprudencia.

Sherwell, B. (1929). Mexico's Capacity to Pay: A General Analysis of the Present International Economic Position in Mexico. U.S.A.

Solís, L. (2000). La realidad económica mexicana: retrovisión y perspectivas. México: Siglo XXI Editores.

Tamagna, F. (1963). La banca central en América Latina. México: Centro de Estudios Monetarios Latinoamericanos.

Tamagna, F. (1964). Formulación y ejecución de la política monetaria. México: Centro de Estudios Monetarios Latinoamericanos.

Thompson, J. (1979). Inflation, Financial Markets and Economic Development: The Experience of Mexico. United Kinngdom: JAI Press.

Turrent, E. (2005). Las tres etapas de la autonomía del banco central en México. En Análisis Económico, XX(43). Recuperado de 
https://www.redalyc.org/pdf/413/41304303.pdf

Turrent, E. (2012). Autonomía de la Banca Central en México. Visión histórica. México: Banco de México. Recuperado de https://www.banxico.org.mx/conociendo-banxico/d/\%7B12C571AE-7083-4001-8B1FCFABCF8C7761\%7D.pdf

Turrent, E. (2015a). Historia del Banco de México. Antecedentes, fundación y despegue. Volumen I. México: Banco de México. Recuperado de https://www.banxico.org.mx/publicaciones-y-prensa/e-library/d/\%7B67768246-B89D9E7B-F236-438632D6FCD9\%7D.pdf

Turrent, E. (2015b). Historia del Banco de México. Consolidación y formación de la tormenta. Volumen II. México: Banco de México. Recuperado de https://www.banxico.org.mx/publicaciones-y-prensa/e-library/d/\%7B40B83819-0A46B0CE-38F0-85CED4E06086\%7D.pdf

Turrent, E. (2015c). Historia del Banco de México. El gran reto regulatorio. Volumen III. México: Banco de México. Recuperado de https://www.banxico.org.mx/publicaciones-y-prensa/e-library/d/\%7BB53F6E70-92301DE9-FF50-E01434599266\%7D.pdf

Turrent, E. (2015d). Historia del Banco de México. Banco central heterodoxo. Volumen IV. México: Banco de México. Recuperado de https://www.banxico.org.mx/publicaciones-y-prensa/e-library/d/\%7BFF75D062-0131D79D-ECAF-744D36C14B9B\%7D.pdf

Turrent, E. (2015e). Historia del Banco de México. Reorganización programática. Volumen V. México: Banco de México. Recuperado de https://www.banxico.org.mx/publicaciones-y-prensa/e-library/d/\%7BC6821EDD7D3B-114D-BFB2-4E553D31A3A4\%7D.pdf

Turrent, E. (2015f). Historia del Banco de México. Borrón y cuenta nueva. Volumen VI. México: Banco de México. Recuperado de https://www.banxico.org.mx/publicaciones-y-prensa/e-library/d/\%7BA29D7766-8F0B1ED0-D20C-44FEC2016947\%7D.pdf

Ugarte, S. (1950). Mexico’s Central Bank. En Mexican-American Review, XVIII(1). 